\title{
Assessing the Validity and Reliability of the Questionnaire on Student Learning Online Interests in Biology
}

\author{
Ika Nur Cahyani ${ }^{1, *}$ Agung Wijaya Subiantoro ${ }^{2}$ \\ ${ }^{1}$ Master of Biology Education, Faculty of Mathematics and Natural Sciences, Universitas Negeri Yogyakarta, \\ Indonesia \\ ${ }^{2}$ Department of Biology Education, Faculty of Mathematics and Natural Sciences, Universitas Negeri \\ Yogyakarta, Indonesia \\ *Corresponding author. Email: ikanur.2018@student.uny.ac.id
}

\begin{abstract}
This research aimed to determine the assesing the validity and reliability of the questionnaire on student learning online interests in biology. The type of this research is survey with quantitative description. The subjects in this study were 100 senior high school students year 2018/2019 from five different regions: 33 respondents in DIY, 31 respondents in Central Java, 22 respondents in East Java, 11 respondents in West Java and three respondents in West Sumatera. The respondents were students in Science class of 10-grade $(n=11), 11$-grade $(n=35)$ and 12-grade $(n=54)$. Data was collected by questionnaire. This instrument used the answer or response category based on a Likert scale, where the level score started from the lowest (1) to the highest (4). In this study, analysis method used to determine the eligibility of items in the questionnaire was carried out with the significance of the reliability coefficient. This was performed to calculate the reliability coefficient per item using the reliability analysis with the Alpha Cronbach formula. Based on the analysis of the statement items using SPSS, out of 22 items, 18 items were recognized as valid and four items were considered invalid. On the reliability test, the 22 questions given to 100 respondents had Cronbach's Alpha value of 0.763 , and this showed a sufficient reliability.
\end{abstract}

Keywords: Gadget, Validity, Reliability, Biology

\section{INTRODUCTION}

The development of science and technology is currently very developed so that it influences in life. With this development has changed the view of the public in finding and getting information can be in the form of magazines, newspapers, radio and electronic media can also find sources of information with the internet [1]. In the field of education the use of technology as a form of media and learning innovation. This technology is used as an innovative learning media [2]. Online learning will benefit students in digital competence. Online learning can help learners repeat confusing material until they understand, and can assist faster learners by allowing them to continue as they understand material, without requiring them to sit through repeated explanations and provide interactive experiences between students and the text they access [3].

Learning media has an important role in the learning process where the learning process is basically the process of communicating and sending messages from sender to receiver. The use of educational technology provides an attractive appearance to use learning activities in increasing motivation and interest to learn that students are interested in and beneficial to student skills [4]. Online learning in Indonesia has a positive impact on the development of information technology.

Technology that is integrated in learning is one of the strategies to achieve learning objectives. Gadgets 
are familiar among students, especially high school students [2]. Gadgets that are connected to the internet make it one of the media in finding information. The internet has become an important tool as a provider of learning resources in research and learning, both for teachers and students to share and obtain information. The internet and technology can be used as developing e-learning as learning media. The use of information and communication technology is used in e-learning [5].

There exists a positive correlation use of technology in education. The use of online learning has a positive relationship between students and teachers to create interactive learning. Students show increased demand in virtual field experiences. Online learning modalities encourage student-centered learning [6]. Online learning can be as an online media used in the learning process that supports interaction between users with learning material or with fellow elearning users so that they can gain knowledge and experience learning. With information technology, elearning is able to provide teaching materials and store learning instructions that can be accessed anytime and from anywhere. E-learning does not require a rol (place) as large as conventional classrooms. Thus this technology has shortened the distance between teachers and students [7].

Online education best practices, Finch and Jacobs (2012) [8] have the following advantages: reducing time and costs on the way to school, giving students flexibility to access online learning according to their wishes and being able to adjust the context needs of the subject. Online education opens opportunities when it comes to balancing work, study, and family responsibilities and can increase interaction between students and teachers [9]. Various words in the terms of online education include: online learning, electronic learning (e-learning), distance education, internetbased learning, web-based learning, computer-based learning, telephoto education, cyber learning, mixed learning, distributed learning, virtual learning, etc[10].

Learning media can be used by the teacher to convey learning to students so that it can be conveyed properly teacher can use media learning so that the learning material delivered can be conveyed well to students. It was used in the learning process in order to stimulate attention and interest of the students to have a message and information can be conveyed [11]. Therefore, this study aims to determine the assesing the validity and reliability of the questionnaires on student learning online interest in biology.

\section{RESEARCH METHODS}

\subsection{Method and Time}

This study method used is the survey method with quantitative description. Questionnaires will be given to respondents with Google forms in several senior high schools. This study was conducted at April to May 2019.

\subsection{Subject of Research}

Population is natural sciences' students at DIY, Central Java, East Java, West Java and West Sumatera. Samples are 100 senior high school students.

Table 1. Respondent classification data

\begin{tabular}{|c|c|c|}
\hline & $\begin{array}{l}\text { Classification } \\
\text { Respondent }\end{array}$ & $\mathrm{N}$ \\
\hline \multirow{6}{*}{$\begin{array}{l}\text { based } \\
\text { on } \\
\text { school } \\
\text { origin }\end{array}$} & SMA in DIY & 33 respondents \\
\hline & SMA in Central Java & 31 respondents \\
\hline & SMA di East Java & 22 respondents \\
\hline & SMA di West Java & 11 respondents \\
\hline & $\begin{array}{l}\text { SMA di West } \\
\text { Sumatera }\end{array}$ & 3 respondents \\
\hline & Total & 100 respondents \\
\hline \multirow{4}{*}{$\begin{array}{l}\text { grade } \\
\text { level }\end{array}$} & Class of 10 -grade & 11 respondents \\
\hline & Class of 11 -grade & 35 respondents \\
\hline & Class of 12 -grade & 54 respondents \\
\hline & Total & 100 respondents \\
\hline
\end{tabular}

Respondent classification data based on school origin. The subjects in this study were 100 high school students year 2018/2019 from five different regions: 33 respondents in DIY, 31 respondents in Central Java, 22 respondents in East Java, 11 respondents in West Java and three respondents in West Sumatera. Respondent classification data by grade level. The respondents were students in Science class of 10-grade $(n=11), 11$-grade $(n=35)$ and 12-grade $(n=54)$. Data was collected by questionnaire.

\subsection{Questionnaire}

Questionnaires will be given to respondents with google forms in several high schools. The questionnaire instrument consisted of 22 items that were tested on 100 students. It used likert scales totally agree, agree, don't agree and totally disagree. This study is to calculate the validity and reliability of items analysis, analyzed using SPSS. 


\subsection{Data Analysis}

Validity is the extent to which a test measures what it is intended to measure. Validity means measurements related to the suitability and accuracy of the function of the measuring instrument used [12]. Items are said to be valid when the significance value is less than $0.05(<0.05)$ and is declared invalid if the significance value is more than $0.05(>0.05)$. Or it could also determine whether or not the item statement is valid by comparing the values between $r$ tables and $r$ arithmetic. The statement item will be declared valid if the value of $r$ table $<r$ count. Meanwhile, if $r$ table $>\mathrm{r}$ count, the statement item will be declared invalid [13] [14].

Reliability test is a test that shows the tools used to obtain informasi can be to reveal information in the field as a data collection tool. A questionnaire is said to be reliable or reliable if a person's answer to a statement is consistent over time. High and low reliability is expressed by a value called the reliability coefficient, ranging between $0-1$. The reliability test uses the Cronbach Alpha formula which is represented using the Cronbach Alpha coefficient. If the Cronbach Alpha value is 0.7 or higher indicates acceptable internal consistency. Cronbach's alpha is used in studies as an indicator of instrument reliability or scale or internal consistency. Generally, in science education to consider an alpha value of 0.70 as a sufficient measure of reliability [15]. Moreover, the smaller the alpha value indicates the more items that are not reliable. The standard used is alpha $>0.70$ (sufficient reliability).

\section{RESULTS AND DISCUSSION}

Based on testing the results obtained can be seen as follows:

Table 2. Reliability test case processing summary

\begin{tabular}{|l|c|c|}
\hline \multicolumn{1}{|c|}{ Cases } & N & $\%$ \\
\hline Valid & 100 & 82 \\
\hline Excluded $^{a}$ & 22 & 18 \\
\hline Total & 122 & 100 \\
\hline
\end{tabular}

${ }^{a}$ List wise deletion based on all variables in the procedure

From table 2, shows the number of samples or respondents $(\mathrm{N})$. Respondents $=100$ student, questionnaires $=22$ item and analyzed in the SPSS program of $100 \%$ students with a valid number of $82 \%$.
Table 3. Alpha Cronbach's results

\begin{tabular}{|c|c|}
\hline \multicolumn{2}{|c|}{ Reliability Statistics } \\
\hline Cronbach's Alpha & N of Items \\
\hline 0.763 & 22 \\
\hline
\end{tabular}

The result of the analysis using SPSS, on the reliability test. 22 items of statement items tested on 100 respondents had Alpha Cronbach's value of 0.763, it meant sufficient reliability. Its means it is assumed that variations of all items have a positive relationship with variations in variables of student learning online interest in biology.

At the 5\% level it can be shown that the variation of all items together has a positive relationship with the variation in the variable of student learning online interest in biology. Meaning: twenty-two items reviewed are of sufficient reliability. The implication: the twenty-two items reviewed are constructors with sufficient reliability for the variable student learning online interest in biology.

Table 4. Test results for the validity of the questionnaire instruments

\begin{tabular}{|c|c|c|c|}
\hline $\begin{array}{c}\text { Number } \\
\text { Item }\end{array}$ & $\begin{array}{c}\text { Value } \\
\text { Significance }\end{array}$ & $\begin{array}{c}\text { Level } \\
\text { Significant }\end{array}$ & Validity \\
\hline Item 1 & 0.000 & \multirow{21}{*}{0.05} & Valid \\
\hline Item 2 & 0.000 & & Valid \\
\hline Item 3 & 0.188 & & Not Valid \\
\hline Item 4 & 0.146 & & Not Valid \\
\hline Item 5 & 0.000 & & Valid \\
\hline Item 6 & 0.397 & & Not Valid \\
\hline Item 7 & 0.840 & & Not Valid \\
\hline Item 8 & 0.004 & & Valid \\
\hline Item 9 & 0.000 & & Valid \\
\hline Item 10 & 0.000 & & Valid \\
\hline Item 11 & 0.000 & & Valid \\
\hline Item 12 & 0.000 & & Valid \\
\hline Item 13 & 0.010 & & Valid \\
\hline Item 14 & 0.000 & & Valid \\
\hline Item 15 & 0.000 & & Valid \\
\hline Item 16 & 0.000 & & Valid \\
\hline Item 17 & 0.000 & & Valid \\
\hline Item 18 & 0.000 & & Valid \\
\hline Item 19 & 0.000 & & Valid \\
\hline Item 20 & 0.000 & & Valid \\
\hline Item 21 & 0.000 & & Valid \\
\hline
\end{tabular}




\begin{tabular}{|l|l|l|l|}
\hline Item 22 & 0.000 & & Valid \\
\hline
\end{tabular}

Items are said to be valid when the significance value is less than $0.05(<0.05)$ and invalid if the significance value is more than $0.05(>0.05)$. Based on the analysis of statement items using SPSS. It can be seen that out of the 22 item statement items there are 18 item statement items already valid and 4 item statement are invalid.

\section{CONCLUSION}

The results of the analysis of statement items can be concluded that of the 22 item statement items there are 18 item statement items already valid and 4 item statement items invalid. On the reliability test results can be from 22 items of statement items tested on 100 respondents have a Cronbach's Alpha value of 0.763 meaning sufficient reliability. Therefore this questionnaire instrument can be used as a reference for large scale data stabilization.

\section{REFERENCES}

[1] Herowati, Kemandirian Belajar Siswa dalam Online Learning Edmodo di SMKN 1 Sumenep, Jurnal Lentera Sains (Lensa) 6(2) (2016) 99-101. DOI: https://doi.org/10.24929/fkip.v6i2.291

[2] I.R. Lubis, I. Jaslin, Pengembangan Media Pembelajaran Kimia Berbasis Android untuk Meningkatkan Motivasi Belajar dan Prestasi Kognitif Peserta Didik SMA, Jurnal Inovasi Pendidikan IPA 1(2) (2015) 191-201. DOI: https://doi.org/10.21831/jipi.v1i2.7504

[3] C.M.D. Hard, D. Berger, B. Jacob, S. Loeb, M. Hill, Online Learning, Offline Outcomes: Online Course Taking and High School Student Performance, AERA Open 5(1) (2019) 1-7. DOI: https://doi.org/10.1177/2332858419832852

[4] M.D.B. Castro, G.M. Tumibay, A Literature Review: Efficacy of Online Learning Courses for Higher Education Institution Using MetaAnalysis, Education and Information Technologies 24 (2019) 1-19. DOI: https://doi.org/10.1007/s10639-019-10027-Z

[5] V. Arkorful, N. Abaidoo, The Role of ELearning, The Advantages and Disadvantages Of Its Adoption In Higher Education, International Journal of Education and Research 2(12) (2014) 397-410.

[6] L. Pei, H. Wu, Does Online Learning Work Better Than Offline Learning in Undergraduate
Medical Education? A Systematic Review and Meta-Analysis, Medical Education Online 24(1) (2019) 1-13. DOI: https://doi.org/10.1080/10872981.2019.1666538

[7] P.L. McDonald, K.J. Harwood, J.T. Butler, K.S. Schlumpf, C.W. Eschmann, D. Drago, Design for Success: Identifying A Process for Transitioning to An Intensive Online Course Delivery Model in Health Professions Education, Medical Education Online 23(1) (2018) 1-10. DOI:

https://doi.org/10.1080/10872981.2017.1415617

[8] D. Finch, K. Jacobs, Online education: Best practices to promote learning, in: Proceedings of the 56th annual meeting of the Human Factors and Ergonomics Society, vol. 56, Informs, Catonsville, Maryland, 2012, pp. 546-550. DOI: https://doi.org/10.1177/1071181312561114

[9] B.S. Bell, J.E. Federman, E-learning in Postsecondary Education, The Future of Children 23(1) (2013) 165-185. DOI: https://doi.org/10.1353/foc.2013.0007

[10] A. Sun, X. Chen, Online Education and Its Effective Practice: A Research Review, Journal of Information Technology Education: Research 15 (2016) 157-190. DOI: https://doi.org/10.28945/3502

[11] E. Marpanaji, M.I. Mahali, R.A.S. Putra, Survey on how to select and develop learning media conducted by teacher professional education participants, in: Journal of Physics: Conference Series, vol. 1140, IOP Publishing, Bristol, 2018 pp. 1-10. DOI: https://doi.org/10.1088/1742$\underline{6596 / 1140 / 1 / 012014}$

[12] H. Taherdoost, Validity and Reliability of The Research Instrument; How to Test The Validation of A Questionnaire/Survey in A Research, International Journal of Academic Research in Management (IJARM) 5(3) (2016) 28-36.

DOI: http://dx.doi.org/10.2139/ssrn.3205040

[13] R. Zaki, Validation of instrument measuring continuous variable in medicine, in: T. Hokimoto (Ed.), Advances in Statistical Methodologies and Their Application to Real Problems, IntechOpen, London, 2017, pp. 218-219. DOI: https://doi.org/10.5772/66151

[14] R. Bukenya, A. Ahmed, J.M. Andrade, D.S.G. Toussaint, J. Muyonga, J.E. Andrade, Validity 
and Reliability of General Nutrition Knowledge Questionnaire for Adults in Uganda, Nutrients 9(2) (2017) $\quad 172 . \quad$ DOI: https://doi.org/10.3390/nu9020172

[15] K. S. Taber, The Use of Cronbach's Alpha When Developing and Reporting Research Instruments in Science Education, Research in Science Education 48(1) (2018) 1-24, DOI: https://doi.org/10.1007/s11165-016-9602-2 